\title{
IMPLEMENTATION OF BEHAVIORISTIC THEORY IN ONLINE LEARNING OF INDONESIAN LESSONS IN CLASS IV OF ELEMENTARY SCHOOL
}

\author{
Maya Nurani Faiza \\ mayanurani99@gmail.com \\ Pendidikan Dasar, Pascasarjana, Universitas Negeri Surabaya
}

\begin{abstract}
The purpose of this research is to find out changes in behavior (behavioristic) in learning Indonesian in reading, writing, and listening skills in grade IV at SDN Karang Entang Bangkalan. This study used qualitative research methods conducted online. The types of data in this study are quantitative and descriptive qualitative data obtained from the sample group, then divided by the number of samples. Based on the results of the research conducted, the percentage of listening skills material obtained is $72 \%$ in very good criteria. On the material of reading skills, it is $95 \%$ in very good criteria. On the material of writing skills, that is $81 \%$ on very good criteria. From these results, it is stated that learning Indonesian on the material of listening, reading, and writing skills by using behavioristic theory, teachers can change and shape student behavior, including increasing knowledge, improving attitudes, and increasing skills and making learning more effective and meaningful.
\end{abstract}

Keywords: Behavioristic, online, behavior change, listening skills, reading skills, writing skills, Indonesian.

\section{IMPLEMENTASI TEORI BEHAVIORISTIK DALAM PEMBELAJARAN DARING MATA PELAJARAN BAHASA INDONESIA PADA KELAS IV SD}

\begin{abstract}
Abstrak: Tujuan penelitian ini yaitu untuk mengetahui perubahan tingkah laku (behavioristik) dalam pembelajaran Bahasa Indonesia pada materi keterampilan membaca, menulis, dan menyimak pada kelas IV di SDN Karang Entang Bangkalan. Penelitian ini menggunakan metode penelitian kualitatif yang dilakukan secara daring. Jenis data pada penelitian ini yaitu kuantitatif dan kualitatif deskriptif yang diperoleh dari data kelompok sampel, kemudian dibagi dengan jumlah sampel tersebut. Berdasarkan hasil penelitian yang dilakukan, diperoleh hasil persentase pada materi keterampilan menyimak yaitu $72 \%$ dalam kriteria sangat baik. Pada materi keterampilan membaca yaitu 95\% dalam kriteria sangat baik. Pada materi keterampilan menulis yaitu $81 \%$ pada kriteria sangat baik. Dari hasil tersebut menyatakan bahwa pembelajaran Bahasa Indonesia pada materi keterampilan menyimak, membaca dan menulis dengan menggunakan teori behavioristik guru mampu
\end{abstract}


Maya. Implementation of Behavioristic Theory...

mengubah dan membentuk tingkah laku siswa diantaranya pengetahuannya bertambah dan semakin bertambah, sikapnya semakin membaik, dan keterampilan yang dimiliki semakin banyak dan membuat pembelajaran lebih efektif serta bermakna.

Kata Kunci : Behavioristik, daring, perubahan tingkah laku, keterampilan menyimak, keterampilan membaca, keterampilan menulis, bahasa Indonesia.

\section{INTRODUCTION}

Learning is a process of interaction between students and educators and learning resources in a learning environment. There are five concepts in this sense, they are (1) interaction, (2) students, (3) educators, (4) learning resources, and (5) learning environment (Hayati, 2017:3). Based on this explanation, it can be concluded that learning is a process of teaching and learning activities that collaborate in an integrated manner into interaction or communication between teachers and students, as well as between students and students during the learning process. Philosophically, learning, in essence, is more down to earth or humanist, not only because it emphasizes the importance of implementing the educational process by paying more attention to the development and growth of children, but also because it emphasizes the importance of completing children's needs and helping the development of children's talents, interests, and abilities.

Behavioristic learning is an effort to form appropriate behavior or desired behavior. Behavioristic learning is often referred to as stimulus-response learning. Human behavior is controlled by rewards or reinforcement from the environment which is one of the components in this theory. The student's behavior is a reaction to the environment and that all behavior is the result of learning. Behavioristic learning can improve the quality of learning if its application is reintroduced in learning. Based on its components, this theory is relevant if used in current learning.

The implementation of behavioristic theory is easy to find in schools now. This is because it is easy to apply this theory to improve the quality of students. One example of its implementation is the existence of a point system when students violate school rules. The intended target of this learning is to change the behavior of students for the better. In addition to giving points for violating school rules, behaviorism is also applied in learning.

Based on the results of initial observations made by researchers at SDN Karang Entang Kwanyar Bangkalan for fourth-grade students online through the Whatsapp Group platform, the reality encountered by researchers was that during the theme learning activities, 
Maya. Implementation of Behavioristic Theory...

which included Indonesian subjects, did not run effectively and optimally because the Indonesian subjects, especially on the topic of listening, reading and writing students are only limited to listening to lectures from the teacher and there does not appear to be a change that occurs after the learning is completed. This means that teachers and students lack the stimulus and response. This causes learning to be less meaningful. It is also not able to provide a realistic description of the concept that the teacher explains to make students understand the material abstractly. Meanwhile, based on the results of interviews with Mr. Rifa'i as a fourth-grade teacher, he received information that in online learning activities the teacher only used the zoom platform and sometimes only distributes assignments in text form (word) in WhatsApp groups. As a result, students cannot obtain real information and result in unsatisfactory student learning outcomes.

From the results of the analysis, it can be seen that even though online learning is certainly needed, a learning atmosphere is needed with a pleasant and interesting stimulus and response so that students do not easily feel bored, lazy, and sleepy. Researchers provide solutions through the Implementation of Behavioristic Theory in Online Learning Indonesian Subjects in Class IV Elementary School. This is expected to make teachers provide attractive stimuli to students and students are interested, more active, and more enthusiastic during the learning process and get satisfactory learning outcomes through behavioral changes that adhere to behavioristic theory.

Based on the description above, the objectives of this study are 1) to describe the behavioral (behavioristic) learning methods identified in learning listening, reading, and writing skills in class IV at SDN Karang Entang Bangkalan. 2) describe changes in behavior (behavioristic) in learning listening, reading, and writing skills in class IV at SDN Karang Entang Bangkalan.

\section{METHOD}

The type of research used is a descriptive qualitative approach with the research subject of teachers and fourth-grade students at SDN Karang Entang Kwanyar Bangkalan. The qualitative research method is a research method based on the philosophy of postpositivism, used to examine the condition of natural objects, where the researcher is the key instrument and the data analysis is inductive or qualitative. Sugiyono (2009:9). 
Maya. Implementation of Behavioristic Theory...

To collect data then used the method of observation and interviews. Data is the result of recording from research either in the form of facts or in the form of numbers as material for composing information (Arikunto 2006:118). According to Lofland in Moleong (2007:157) the data used in qualitative research are words and actions as the main data source, while documents and others are additional data. A research instrument is a tool used to measure the observed natural or social phenomena (Sugiyono 2009:102). The research instruments used in this study were observation and interviews.

The data obtained are presented in the form of tables, charts, and descriptions. The description of the data is obtained in the form of a percent.

$$
\% \frac{\text { number of parts }}{\text { total number } x} 100 \%
$$

The average value is calculated by adding up all the data values for the sample group, then dividing by the number of samples. So if a group random sample with the number of samples $\mathrm{n}$, then the sample value can be calculated as follows.

$$
\mathrm{x}=\sum_{n=1}^{n} x^{1} \quad \text { Sugiyono, 2011) }
$$

\section{RESULTS AND DISCUSSION}

\section{RESULTS}

The research results that have been obtained are formulated following the objectives of this study, they are:

1) Describe the behavioral learning methods (behavioristics) identified in learning listening, reading, and writing skills in class IV at SDN Karang Entang Bangkalan.

Table 1. (Behavioral learning methods (behavioristic) in class IV at SDN Karang Entang Bangkalan)

\begin{tabular}{|c|c|c|c|}
\hline No & Skill type & $\begin{array}{c}\text { Behavioral learning method (behavioristic) in class IV at } \\
\text { SDN Karang Entang Bangkalan }\end{array}$ \\
\hline 1. & Listening skills & $\bullet \quad$ Listen and write method \\
& Reading skills & Identify keywords \\
\hline 2. & Writing skills & The syllabic method (Syllabic Method) \\
& & $\bullet$ & Sentence/global method (Syntaxis Method) \\
\hline 3. & & $\bullet$ & Constructivist method \\
\hline
\end{tabular}


Maya. Implementation of Behavioristic Theory...

Source: Researcher Data

2) Describe changes in behavior (behavioristic) in learning listening, reading, and writing skills in class IV at SDN Karang Entang Bangkalan.

To find out the results of the analysis of each response item with predetermined effectiveness criteria:

Table 2. (Percentage of response item analysis results)

\begin{tabular}{|c|c|c|}
\hline No & Percentage & Criteria \\
\hline 1. & $71 \%-100 \%$ & Very good \\
\hline 2. & $61 \%-80 \%$ & Good \\
\hline 3. & $41 \%-60 \%$ & Enough \\
\hline 4. & $0 \%-40 \%$ & Not enough \\
\hline
\end{tabular}

Source: Arifin (2016)

\section{Listening Skills}

Listen and write method

Table 3. (Indicators of Assessment of Listening Skills for Listening and Writing Method)

\begin{tabular}{|c|c|c|c|c|c|}
\hline \multirow{2}{*}{ No } & Rating indicators & \multicolumn{3}{|c|}{ Achievement rate } \\
\cline { 3 - 5 } & & $\mathbf{1}$ & $\mathbf{2}$ & $\mathbf{3}$ & $\mathbf{4}$ \\
\hline 1. & Understanding the content of the discourse & & & & 5 students \\
\hline 2. & Discourse content disclosure skills & & & & 4 students \\
\hline 3. & Smooth disclosure & & & 4 students & \\
\hline 4. & Correct sentence structure & & & 5 students & \\
\hline 5. & Courage of speech & & 4 students & \\
\hline
\end{tabular}

Source: Nurgiyantoro (2013)

\section{Keyword Identification Method}

Table 4 (Indicators of the Assessment of Listening Skills for Keyword

\section{Identification Methods)}

\begin{tabular}{|c|c|c|c|c|c|}
\hline \multirow{2}{*}{ No } & Rating indicators & \multicolumn{3}{|c|}{ Achievement rate } \\
\cline { 5 - 6 } & Understanding the content of the discourse & & & & $\mathbf{3}$ \\
\hline 1. & Discourse content disclosure skills & & & & 3 students \\
\hline 2. & Smooth disclosure & & & 4 students & \\
\hline 3. & Correct sentence structure & & & 2 students & \\
\hline 4. & Courage of speech & & & & 7 students \\
\hline 5. & C S & & & \\
\hline
\end{tabular}

Source: Nurgiyantoro (2013) 
Maya. Implementation of Behavioristic Theory...

Based on the results of calculations in the form of percent of the two methods of listening skills, it can be seen in a chart like the following:

\section{LISTENING SKILLS}

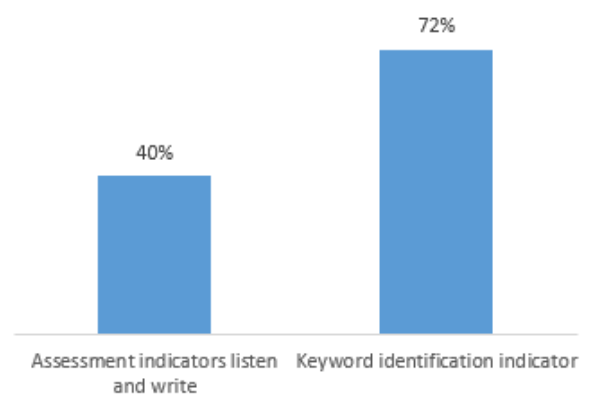

Source: Research data

\section{Reading Skills}

Syllable Method Assessment Indicators

Table 5 (Indicators of Reading Skills Assessment of the Syllable Method)

\begin{tabular}{|c|c|c|c|c|c|}
\hline \multirow{2}{*}{ No } & Rating indicators & \multicolumn{4}{|c|}{ Achievement rate } \\
\cline { 3 - 5 } & & $\mathbf{1}$ & $\mathbf{2}$ & $\mathbf{3}$ & $\mathbf{4}$ \\
\hline 1. & Diction accuracy and language style & & & & 11 students \\
\hline 2. & Smooth disclosure & & & 1 student & \\
\hline 3. & Courage of speech & & & 1 student & \\
\hline 4. & Correct sentence structure & & & & 9 students \\
\hline
\end{tabular}

Source: Nurgiyantoro (2013)

\section{Sentence/Global Method}

Table 6 (Indicators of Reading Skills Assessment Sentence/Global Method)

\begin{tabular}{|c|c|c|c|c|c|}
\hline No & Rating indicators & \multicolumn{4}{|c|}{ Achievement rate } \\
\cline { 3 - 5 } & & $\mathbf{1}$ & $\mathbf{2}$ & $\mathbf{3}$ & $\mathbf{4}$ \\
\hline 1. & Diction accuracy and language style & & & & 7 students \\
\hline 2. & Smooth disclosure & & & & 4 students \\
\hline 3. & Courage of speech & & & 1 student & \\
\hline 4. & Correct sentence structure & & & & 9 students \\
\hline
\end{tabular}

Source: Nurgiyantoro (2013) 
Maya. Implementation of Behavioristic Theory...

Based on the results of calculations in the form of percent of the two methods of reading skills, it can be seen in the following chart:

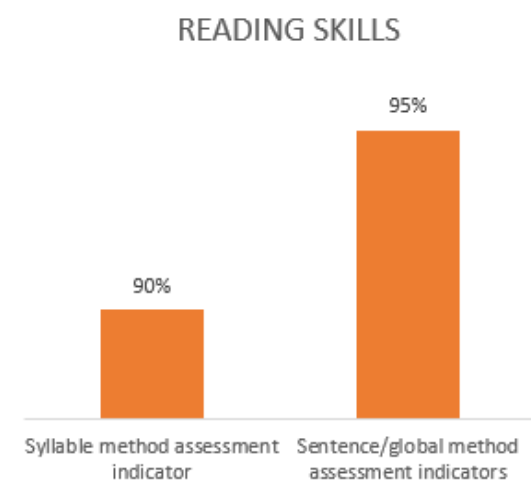

Source: Research data

\section{Writing skills}

Communicative Method Assessment Indicators

Table 7 (Indicators of Communicative Method Writing Skills Assessment)

\begin{tabular}{|c|c|c|c|c|c|}
\hline \multirow{2}{*}{ No } & \multirow{2}{*}{ Rating indicators } & \multicolumn{3}{c|}{ Achievement rate } \\
\cline { 3 - 6 } & & $\mathbf{1}$ & $\mathbf{2}$ & $\mathbf{3}$ & $\mathbf{4}$ \\
\hline 1. & Diction Accuracy & & & & 3 students \\
\hline 2. & The suitability of the writing topic & & & & 7 students \\
\hline 3. & Correct sentence structure & & & & 3 students \\
\hline 4. & The breadth of the writing material & & & 4 students & \\
\hline
\end{tabular}

Source: Nurgiyantoro (2013)

\section{Constructivist Method}

Table 8 (Indicators of Constructivist Writing Skills Assessment)

\begin{tabular}{|c|c|c|c|c|c|}
\hline No & Rating indicators & \multicolumn{4}{|c|}{ Achievement rate } \\
\cline { 3 - 5 } & & $\mathbf{1}$ & $\mathbf{2}$ & $\mathbf{3}$ & $\mathbf{4}$ \\
\hline 1. & Diction Accuracy & & & & 3 students \\
\hline 2. & The suitability of the writing topic & & & & 7 students \\
\hline 3. & Correct sentence structure & & & & 3 students \\
\hline 4. & The breadth of the writing material & & & $\begin{array}{c}4 \\
\text { student } \\
\text { s }\end{array}$ & \\
\hline
\end{tabular}

Source: Nurgiyantoro (2013)

Based on the results of calculations in the form of percent of the two methods of writing skills, it can be seen in a chart like the following: 


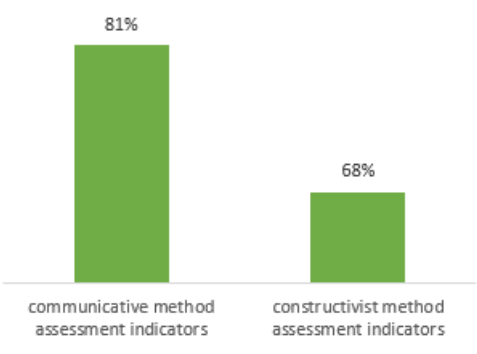

Source: Research data

\section{DISCUSSION}

The discussion of the research that has been obtained is formulated following the objectives of this study and the results obtained during the research, they are:

1) Describe the behavioral learning methods (behavioristics) identified in learning listening, reading, and writing skills in class IV at SDN Karang Entang Bangkalan.

Based on the results of interviews with the homeroom teacher for class IV, Mr. Rifa'I, S.Pd., it was found that the following is a behavioral learning method (behavioristic) identified in learning reading, writing, and listening skills in class IV at SDN Karang Entang Bangkalan. The thing that becomes a pressing point in the process of learning in students is the emergence of a relationship between stimulus and response. This relates to what behavior is shown by students, so it is important to pay attention to other things so that teachers can detect or conclude that the learning process has been successful. What is meant is as follows:

1. Teachers should understand what kind of stimulus is right to be given to students.

2. The teacher also understands what kind of response will appear in students.

3. To find out whether the response shown by this student is following what is expected, the teacher must be able to: a. Determine that the response can be observed (observable) b. The responses shown by students can also be measured (measurable) c. The response shown by students should be stated explicitly or clarify the meaning (explicit) d. So that the response can always continue to occur or be faithful in the memory/behavior of students, it is necessary to have some kind of reward. 
Mava. Implementation of Behavioristic Theory...

Behavioristic theory views that knowledge has been structured neatly and orderly, so students or people who learn must be faced with clear and strictly defined rules beforehand. Habituation and discipline are very essential in learning, so learning is more associated with discipline enforcement. Failure or inability to gain knowledge is categorized as an error that needs to be punished and learning success or ability is categorized as a form of behavior that deserves to be rewarded. Likewise, adherence to rules is seen as a determinant of learning success. Learners or students are objects that behave following the rules, so learning control must be held by a system that is outside of the learner.

The behavior observed by the researcher was in the form of behavior that emerged from most of the students in the class being studied. Based on the results of the study, two responses or student behavior emerged, namely verbal responses and nonverbal responses. Based on the research that has been done, the desired student behavior appears in the learning objectives.

\section{Listening skills}

Listening is one aspect of language skills. Listening is closely related to speaking, reading, and writing. However, the relationship between listening and speaking is closer than the relationship between listening and reading or listening and writing. Oral communication will not work if listening is not accompanied by speaking or vice versa speaking must be accompanied by listening activities. Indonesian teachers in elementary schools should strive to make listening teaching enjoyable for students. This can be done if the teacher mastered the material and ways or methods of teaching listening. Especially in the listening teaching method, the teacher must recognize, understand, appreciate, and be able to practice various ways of teaching listening.

The listening learning methods include:

a. Listen and write

In this technique, the teacher reads or plays to a short discourse (heard only once). Students listen well.

b. Identify keywords 
Maya. Implementation of Behavioristic Theory...

In listening to a sentence, paragraph, or long discourse, we do not need to catch all the words but just remember the keywords. Keywords are the core of a long sentence, paragraph, or discourse.

\section{Reading Skills}

Reading skills need to be mastered by every student. First, when students are in the process of completing their studies, reading skills are needed in learning each subject. Every subject must have a textbook that must be digested by students. Second, if students later engage in social life outside of school, reading skills are still very necessary.

a. Syllabic Method (Syllabic Method)

This method begins with the introduction of syllables such as ba, bi, bu, be, bo, ca, ci, cu, ce, co, da, di, du, de, do, and so on. Then the syllables are assembled into meaningful words.

b. Sentence Method/ Global (Syntaxis Method)

The Global Method is a way of learning to read complete sentences. The Global Method is based on a sentence approach. The trick is that the teacher teaches reading by displaying sentences under the picture.

\section{Writing Skills}

Writing means expressing writing notions, ideas, opinions, or thoughts and feelings. The tool of making this happen is language. The contents of the expression through that language will be understood by other people or readers if it is poured in an orderly, systematic, simple, and easy to understand language. The skill of expressing thoughts through language that is regular, systematic, simple, and easy to understand is what Indonesian teachers must train their students. This can be achieved through targeted and planned writing exercises. For example, writing exercises in the simplest, usual, and difficult forms.

In learning to write, several methods are used, they are:

a. Communicative Method

Designs that contain communicative methods must cover all language skills. Each goal is organized into learning. Each learning is specified into a concrete goal which is the final product. For example, the communicative method can be done by writing dialogue 
Maya. Implementation of Behavioristic Theory...

techniques. Students write dialogue about what they did in an activity. This activity can be carried out individually or in groups.

b. Constructivist Method

The central assumption of the constructivist method is learning is discovering. This means that even though the teacher conveys something to students, they carry out mental processes or brain work on the information so that the information enters their understanding. Constructivism starts from problems that often arise from students themselves and then helps students solve and find steps to solve these problems.

2) Describe changes in behavior (behavioristic) in learning listening, reading, and writing skills in class IV at SDN Karang Entang Bangkalan.

Based on observations during the learning process, it was found that behavioral changes (behavioristic) in learning reading, writing, and listening skills in class IV at SDN Karang Entang Bangkalan are as follows:

\section{Listening Skills}

\section{Indicator Assessment Method Listen to write}

At this stage, the teacher reads or plays a short discourse related to the beginning of the spread of the covid virus in Indonesia. The teacher only plays to the students once enough. After that, students were asked to repeat the discourse that the teacher had said.

From the assessment indicators, it was found that 9 students understood the discourse content, the accuracy of sentence structure, the courage of narrative with the level of achievement of 4 . While skills of disclosing discourse content, and the fluency of disclosure were with the level of achievement of 3 . There were 13 students with the skills of disclosing discourse content and fluency disclosure with the level of achievement of 4 . While the understanding of discourse content, the accuracy of sentence structure, the courage of narrative, namely the level of achievement of 3 .

\section{Keyword Identification Method Indicator}

In this case, students listen to a sentence, paragraph, or long discourse, students do not need to catch all the words but just remember the keywords. Keywords are the core of a long sentence, paragraph, or discourse. 
Mava. Implementation of Behavioristic Theory...

From the assessment indicators, it was found that 16 students understood the content of discourse, the accuracy of sentence structure, the courage of narrative, the accuracy of sentence structure, the fluency of disclosure with the level of achievement of 4 . While the skill of disclosing the discourse content was with the level of achievement of 3 . There were 6 students with the skill of disclosure content of discourse and fluency of disclosure, Courage of speech with the level of achievement of 4 . While understanding of discourse content, the accuracy of sentence structure, fluency of disclosure that is with the level of achievement of 3.

According to the chart results, it can be concluded that the method of listening skills in the written listening assessment is getting a score of $40 \%$ which is included in the sufficient category. Meanwhile, in the assessment of keyword identification, a score of $72 \%$ was included in the very good category. Students tend to be more active in the key identification method than in the written assessment.

\section{Reading Skills}

\section{Syllable Method Assessment Indicators}

This method begins with the introduction of syllables such as ba, bi, bu, be, bo, ca, ci, $\mathrm{cu}, \mathrm{ce}, \mathrm{co}, \mathrm{da}, \mathrm{di}, \mathrm{du}, \mathrm{de}, \mathrm{do}$, and so on. Then the syllables are assembled into meaningful words.

From the assessment indicators, it was found that there were 20 students with accuracy in diction and language style, fluency in disclosure, courage in speech, and accuracy in sentence structure with an achievement level of 4 . There were 2 students with speaking courage and speaking fluency with an achievement level of 3.

\section{Sentence/Global Method Assessment Indicators}

Students learn how to learn to read complete sentences. The Global Method is based on a sentence approach. The trick is that the teacher teaches reading by displaying sentences under the picture. In addition, the Global Method can also be applied in sentences, without the help of pictures.

From the assessment indicators, it was found that there were 21 students with accuracy in diction and language style, fluency in expression, courage in speech, and 
Maya. Implementation of Behavioristic Theory...

accuracy in sentence structure with an achievement level of 4 . There was 1 student of speaking courage with an achievement level of 3 .

According to the chart results above, it can be concluded that the method of reading skills in the assessment of the Syllable Method, which is $90 \%$, is included in the very good category. Meanwhile, the Sentence/Global Method assessment is included in the very good category, which is $95 \%$. Students are actively involved and happy in the learning process using two methods on the reading skills material.

\section{Writing skills}

\section{Communicative Method Assessment Indicators}

The communicative method can be done by writing the dialogue technique. Students write dialogue about what they did in an activity. This activity can be carried out individually or in groups.

From the assessment indicators, it was found that there were 18 who wrote with the accuracy of diction, the suitability of writing topic, the accuracy of sentence structure, the breadth of writing material with the level of achievement of 4.4 students wrote with the breadth of the writing material at the level of achievement of 3.

\section{Constructivist Method Assessment Indicators}

The teacher conveys something to students, they carry out mental processes or brain work on the information so that the information enters their understanding. Constructivism starts from problems that often arise from students themselves and then helps students solve and find steps to solve these problems.

From the assessment indicators, it was found that there were 15 who wrote with the accuracy of diction, the suitability of writing topic, the accuracy of sentence structure, the breadth of writing material with the level of achievement of 4.7 students wrote with the breadth of the writing material at the level of achievement of 3 .

According to the chart results above, it can be concluded that the method of writing skills in the Communicative Method assessment, which is $81 \%$, is included in the very good category. Meanwhile, in the Constructivist Method, 68\% was included in the very good 
Mava. Implementation of Behavioristic Theory...

category. Students are actively involved and happy in the learning process using two methods in the writing skill material.

\section{CONCLUSIONS AND SUGGESTIONS}

Based on the results of the study it can be concluded that:

1) Behavioral learning methods (behavioristic) identified in learning listening skills in class IV at SDN Karang Entang Bangkalan consist of listening and writing methods, identifying keywords. The behavioral learning method (behavioristic) identified in learning reading skills in class IV at SDN Karang Entang Bangkalan consists of the syllabic method (Syllabic Method), the sentence/global method (Syntaxis Method). While the behavioral learning methods (behavioristic) identified in learning writing skills in class IV at SDN Karang Entang Bangkalan consist of communicative methods, constructivist methods.

2) Changes in behavior (behavioristic) in learning listening, reading, and writing skills in class IV at SDN Karang Entang Bangkalan, which is learning Indonesian in listening, reading, and writing skills using behavioristic learning theory carried out by teachers and students during the learning process good to very good results. Class teachers can change and shape student behavior in the Indonesian learning process on listening, reading, and writing skills using behavioristic learning theory with the help of special methods that the teacher has prepared. As well as being able to change students towards goodness, including increasing and increasing knowledge, improving attitudes, and increasing skills. This is following the results of the percentage of response item analysis results obtained. In the listening skill, the reading and writing assessment indicator scored $40 \%$, while the keyword identification indicator scored $72 \%$. The reading skill in the syllable method assessment indicator gets a score of $90 \%$ while the sentence/global method assessment indicator gets a $95 \%$ score. The writing skill in the communicative method assessment indicator scored $81 \%$ while the constructivist method assessment indicator scored $68 \%$. The reading skill in the syllable method assessment indicator gets a score of 90\% while the sentence/global method assessment indicator gets a $95 \%$ score. The writing skill in the communicative method assessment indicator scored $81 \%$ while the constructivist method assessment indicator scored 68\%. The reading skill in the syllable method assessment indicator gets a score of $90 \%$ while the sentence/global method assessment indicator gets a $95 \%$ score. The writing skill in the communicative method 
Maya. Implementation of Behavioristic Theory...

assessment indicator scored $81 \%$ while the constructivist method assessment indicator scored $68 \%$.

Suggestions in this study are that it can be used as an experience that learning Indonesian in listening, reading, and writing skills using behavioristic learning theory assisted by special learning methods can make students more enthusiastic about learning and can make students understand the material more concretely. It is hoped that all Indonesian teachers can convey material in a fun way and that the teacher always involves students in the learning process so that the learning process runs smoothly, meaningfully, effectively, creatively and students get satisfactory learning outcomes. From changes in behavior to the good of the students, if the behavior is carried out continuously it will become the child's character.

\section{THANK-YOU NOTE}

The researcher would like to thank Allah SWT for the abundance of grace and guidance so that this research can be completed properly. Furthermore, the researcher would like to thank both parents who always pray for and do not forget to SDN Karang Entang Kwanyar Bangkalan for being willing to give space and time during the research process.

\section{REFERENCES}

Arifin, Zainal. 2016. Evaluasi Pembelajaran Prinsip, Tenik, dan Prosedur. Bandung: PT Remaja Rosadakarya.

Dimyati dan Mudjiono. 2006. Belajar dan Pembelajaran. Jakarta: PT Rineke. Cipta. Joko Suwandi. 2011. Penelitian Tindakan Kelas. Surakarta: PSKGJ- FKIP.

Sugiyono. 2016. Penelitian \& Pengembangan (Research and Development). Bandung: Alfabeta

Ibrahim, Hervino. Teori Belajar Perilaku”. Mister Phsics Education. 2012. (online) (http://misterphysicseducation.blogspot.com/2012/11/teori-belajar-perilaku.html). Akses Pada Jumat, 19 November 2021.

Nahar, Novi Irwan. Penerapan Teori Belajar Behavioristik Dalam Proses Pembelajaran. Jurnal Ilmu Pengetahuan Sosial Vol.1. http://eprints.umsida.ac.id

Syafaruddin. Teori Belajar Behavioristik. Jurnal Kajian Islam \& Pendidikan Vol.8. No.2. http://journal.iaimsinjai.ac.id/index.php/al-qalam 
Mava. Implementation of Behavioristic Theory...

Novi Irwan Nahar. Penerapan Teori Belajar Behavioristik Dalam Proses Pembelajaran. Jurnal Ilmu Pengetahuan Sosial Vol.1. No.1. http://jurnal.um-tapsel.ac.id

RK Rusl. Teori Belajar Dalam Psikologi Pendidikan Theory Of Learning According To Educational Psychology. Jurnal Sosial Humaniora Vol.4. No.2. http.//unidajump.ac.id Dliyauddin, Arie, Zainul Abidin, and Agus Wedi. Penerapan Prinsip Belajar Behavioristik Dalam Kegiatan Muhadharah Di Tarbiyatu Muallimien Al-Islamiyah Pondok Al-Amien Prenduan Sumenep Madura. Jurnal Kajian Teknologi Pendidikan. Vol.8. No. 3 https://doi.org/10.17977/um038v2i32019p166.

Hermansyah Hermansyah. Analisis Teori Behavioristik (Edward Thordinke) dan Implementasinya dalam Pembelajaran SD/MI. Vol.7. No.1. https://doi.org/10.36835/modeling.v7i1.547

Siti Maghfhirah. Pemikiran Behaviorisme Dalam Pendidikan (Study Pendidikan Anak Usia Dini). Vol.6. No.2. http://jurnal.tapsel.ac.id

Budiningsih. Elajar Dan Pembelajaran Berdasarkan Teori Psikologi Belajar Behavioristik. Vol.22. No.2. https://doi.org/10.17509/jpis.v22i1.2200

Murniyati. Penerapan Teori Belajar Behavioristik Skinner Dalam Pembelajaran Baca Tulis Al-Qur'an Di SDIT Alam Nurul Islam Yogyakarta. Vol.11. No.2. https://doi.org/10.47200/ulumuddin.v11i2.895

Izzatur Rusuli. Refleksi Teori Belajar Behavioristik Dalam Perspektif Islam. Vol.8. No.1. https://doi.org/10.13170/jp.8.1.2042 